\title{
The opening of Cold War Archives and the Rewriting of Jimmy Carter's Policy in Africa: Reconsidering the Cold War factor
}

\author{
Samia Kouki \\ Higher Institute of Langues of Tunis, Tunisia. \\ Email: samiakouki2000@yahoo.fr
}

Doi: 10.5901/mjss.2013.v4n4p225

\section{Abstract}

\begin{abstract}
During the Cold War, strategic considerations relating to the need to contain and reverse Communist influence in Africa colored different American administrations' policy and prevented an unbiased approach to the various issues of the region, including the open racism practiced against large sections of its population, and the glaring lack of commitment to human rights among many of its leaders. The presidency of Jimmy Carter was generally perceived as an exception to that general rule, and the historical verdict on his African diplomacy is mostly a positive one. Carter and his foreign policy aids were believed to have downplayed a factor that was a fixture for other administrations, namely the role of the Cold War in shaping official attitude to the moral problems and dilemmas of that continent. Shortly after the Cold War era, however, the United States government started to declassify a considerable portion of governmental documents relating to that period. The new documentation has cast the dominant assumptions relating to anti-Communism and Carter's policy in Africa under a completely different light and allowed the possibility for the rewriting of a more accurate assessment of his administration's agenda for Africa. Relying primarily on some of this declassified data, this research aims to tackle the following questions: what was the real role played by American containment objectives in formulating the African agenda of Jimmy Carter? How different was his administration from others in that regard? And did Carter truly give priority to morality over interest in his approach to Africa?
\end{abstract}

Keywords: Jimmy Carter, Cold War, Declassification, Africa, human rights.

\section{Introduction}

American-Soviet relations have always been driven by a complex intermingling of themes, namely competition, fear and mutual suspicion. During the post Second World War era the distinct differences in the political systems of the two countries started to be translated into an increasingly open display of hostility, and the gap between both protagonists grew even wider. This intense period of East-West competition, rivalry, and conflict short of full scale war, had for name the Cold War and since its onset, it had become an important context for studying American foreign policy. This research deals with the impact of such rivalry on Carter's policy in Africa in light of declassified governmental document from the Cold War era.

During this era, strategic considerations relating to the need to contain and reverse Communist influences in Africa colored different administrations' course of action, and prevented an unbiased approach to the various issues of the region. Jimmy Carter's approach was generally perceived as an exception to that general rule. Carter and his foreign policy aides were believed to have downplayed the Cold War factor and to have initiated an alternative, human rightsoriented approach. However, declassified Cold War documentation has cast the dominant assumptions relating to antiCommunism and Carter's policy in Africa under a completely different light and allowed the possibility of the rewriting of a more accurate assessment of his administration's agenda. Relying primarily on some of this declassified data, this research aims to tackle the following issues: the real role played by American containment objectives in formulating the African agenda of Jimmy Carter, the extent to which his administration was different from others in that regard, and whether or not morality was given precedence over interest in Carter's approach to Africa.

\section{American Approach to Africa and the Domination of the Globalist Perspective}

Africa has always been a continent riddled with unrest and moral dilemmas. During the 1970's black Africa's major problems related to a number of armed conflicts and civil wars, in addition to a strong disregard of human rights generated by institutionalized racial segregation. Few months after Carter assumed presidency, a war broke out in the 
Northeastern corner of the continent, most commonly known as the Horn of Africa. The Ogaden war, as it was called, involved the countries of Somalia and Ethiopia and has its roots in the partition of Somalia during the scramble for Africa. While Italy and Britain received the Northern and the Southern parts of the country, Ethiopia was given Ogaden. In 1960, after independence, the North and the South joined in the new state of Somalia. In July 1977, the Somali government took advantage of the political unrest in Ethiopia and invaded Ogaden. The conflict between Somalia and Ethiopia over that territory was to last for the few years to come (Smith, 1986, p. 153).

Also of particular concern to the United States were conditions in neighboring Angola. The country had been ruled by the Portuguese until 1974. The Portuguese withdrawal left a vacuum that was soon filled by three major groups competing for national prominence, the National Union for the Total Independence of Angola (UNITA), the National Liberation Front of Angola (FNLA), and the Popular Movement for the Liberation of Angola (MPLA). A bitter fight for political advantage ensued.

The continent also drew worldwide attention, especially during the second half of the $20^{\text {th }}$ century, because of widespread racial discrimination imposed by minority white governments on large black populations especially in the Southern part of Africa. In Rhodesia, for example, after the British withdrawal in 1965, a group of white settlers led by lan Smith refused to relinquish power. The minority government imposed a rigid and discriminatory rule on blacks and violently crashed opposition which eventually resulted in a worldwide condemnation of Smith's rule (Smith, 1986, p. 141).

The most important moral dilemma facing Africa however was perpetrated by the Afrikaner government of South Africa though an institutionalized system of racial segregation called apartheid. Apartheid was introduced by the South African National Party after its electoral victory in 1948. The system built upon a variety of laws that enabled the white minority to control and violate the rights of blacks and people of mixed races. Blacks were considered second class citizens, were forced to reside in separate and very poorly equipped homelands, were restricted in their right of land ownership, and freedom of movement. They were also subjected to a number of other discriminatory practices including the provision of inferior education and the imposition of a pass legislation requiring them to carry permits without which they would not be able to move inside their own country (Massie, 1998, p. 15-22).

Opposition to apartheid at home was met with violence and oppression. Famous instances include the Sharpeville massacre which occurred in 1960 and the Soweto uprising of 1976, which resulted in the loss of several hundred nonwhite African lives. Because of the extreme human rights abuses inherent in the apartheid system, the plight of South African blacks and colored generated an increased public awareness of apartheid throughout the world, and produced persistent international condemnation of the segregationist regime. As a result, diplomatic pressure mounted abroad for change. In 1961 South Africa was forced to withdraw from the British Commonwealth due to the pressure of the member states who were critical of the rigid discrimination and repression imposed on non-whites. By the 1960's the United Nations had already started to pass a growing number of resolutions directed against apartheid, and by the time Carter became president the racist system was clearly under international strain.

The South African government was also implicated in a diplomatic stalemate that required a sustained international effort at mediation and settlement and that involved the neighboring state of Namibia. The controversy over South West Africa, today's Namibia, started in 1966 when South Africa which was given mandate over the territory following the Second World War, decided to ignore a UN decision to terminate the mandate and continued its occupation of South West Africa. Opposition to South African occupation was led by the South West Africa's People Organization, (SWAPO), which answered white's intransigence with violent guerrilla attacks and which was in turn met with large scale repression. Because of the escalation of tension, the Namibian question became high in UN agenda for African affairs and among world leaders who had to struggle for decades to help achieve an acceptable Namibian settlement (Kline, 1997, p. 64).

Since the onset, the Cold War became a significant context for American policy in the third world. Foreign policy experts distinguish between two distinctive diplomatic approaches to various parts of the globe during that period, the globalist approach and the regionalist approach. The globalist perspective tended to regard the Soviets as the source of all regional and global problems and to view different issues from the lenses of East-West competition. The regionalist approach, however, was said to be stripped of Cold War considerations, and to advocate appropriate solutions for specific problems including armed conflicts and moral issues. As far as Africa was concerned, the globalist approach was said to be dominant. For successive administrations, policies that had for primary objective controlling and restricting the spread of the Communist ideology in African nations dominated American diplomatic effort. Containment was accepted without debate as the appropriate strategy of American foreign policy and the attempt to counter the perceived Soviet threat began to be translated into widely contested policies.

What further reinforced American anti-Communist intentions was a number of developments that took place in the third world following decolonization. Many of the newly independent countries adopted models of government that appeared very close to that of the Soviets, and kept close diplomatic relations with American "totalitarian enemy". These 
developments made it very hard for the United States to separate its African policy from the broader global context. Ensuring the pro-Western government's continued loyalty, at a time when Soviets and their proxies were able to score major gains in the African continent, became a priority under various administrations. Eventually, maintaining an American sense of morality regardless of the strategic interests at stake started to be seen as a luxury that few presidents considered. Indeed, American official reaction to these developments was, to use Ted Carpenter's words "particularly simplistic and unfortunate". This is a reference to a trend whereby anti-Communist governments were supported and aided by the United States, regardless of their policies at home, and democratically elected left-wing regimes were criticized and even fought. Millions were spent in military and economic aid to further that objective. What ensued was blatant disregard of African moral problems.

In fact, apart from issues relating to the broader anti-Communist struggle, Africa in general remained low on the American foreign policy agenda especially compared to other parts of the globe. Historian Peter Schraeder even contends that "US African policies have been marked by indifference at worst and neglect at best" (1994, p. 3). Coauthors Alan Dobson and Steve Marsh contend that "US African policy in the 1950's and 1960's was one of benign neglect of black Africa and generally cautious support of South Africa's white apartheid regime" (2001, p.91). Concerning South Africa and the apartheid regime little was done to reverse such a system and different US administrations' lack of commitment to that moral problem was flagrant. The Dwight D. Eisenhower administration, for instance, was prompt to send an apology to Pretoria after a number of officials in the State Department issued a statement condemning the oppression carried out by the South African government during the Sharpeville events (Borstelmann, 2003, p. 127). John F. Kennedy on the other hand did little more than publicly condemn apartheid, but stood unconcerned when the newly elected South African Prime Minister Hendrick Verwoed banned the ANC and other groups and began a massive sabotage campaign against any dissenting voice. When Lyndon Johnson assumed the presidency, preoccupation with other pressing issues at home and abroad, like the racial problems and Vietnam War protest, moved African dilemmas even lower on the country's international agenda (Coker, 1986, p. 9).

The Nixon administration also embraced a policy of indifference toward African issues and conflicts while strengthening economic and military relations with the pro-Western African governments (Coker, 1986, p. 15-28). Upon Nixon's resignation Secretary of State Henry Kissinger became the major actor in US- African relations. Kissinger resorted to diplomacy and eventually started an African tour during which he carried out talks with different African leaders. The talks were meant to tackle the different issues relating to the African region, namely the problem of Namibia, the restoration of the US image in Africa and the effort to control Communist advances in Angola and Southern Africa. Given the strategic importance of South Africa, confrontation with the Afrikaners government over apartheid was not a policy option and it was consequently disregarded (Schraeder, 1994, p. 213-215).

The trend whereby Cold War concerns overshadowed any other foreign policy consideration was reinforced with the election of Ronald Reagan in 1980. The Republican administration would see that an enhanced role of human rights was out of context, would put less emphasis on morality, and focus its energies on countering the perceived Soviet threat. Believing that "strategically vital parts of the world fell under the shadow of Soviet power," Reagan decided to take a new turn of action to remedy the situation. A new doctrine outlining the contours of the new governmental orientation regarding foreign policy was devised, and was called the "Reagan Doctrine".

The United States therefore did, as author Christopher Coker put it, "stand on the sidelines as a dispassionate, if not disinterested observer" (1986, p. 4). Different American administrations clearly downplayed the moral dimension in their relations with Africa to focus on other strategic imperatives relating to the containment of the Soviets. The reaction, or the absence of reaction, to the major conflicts of the region and to the human rights abuses inherent in discriminatory systems of governments exposes a pattern of lack of concern with the most pressing issues of the African continent. The first indications of a possible change in US foreign policy surfaced when Carter was elected president. His strong rhetoric and renewed emphasis on the priority that should be given to a moral approach to foreign policy convinced many that an alternative regionalist approach to Africa was in sight.

\section{Carter and the Emphasis on Morality}

When Jimmy Carter was elected the $39^{\text {th }}$ president of the United States, a very important shift in the perception and formulation of the objectives of foreign policy appeared imminent. The shift basically consisted of a departure from a vision of American relations abroad building upon what was called "realpolitik" toward a new and different human rightsoriented foreign policy. The foreign policy advocated by Carter appeared fundamentally different from that of his predecessors, mostly from the approach of Henry Kissinger. The former Secretary of State who formulated most of Nixon's and Ford's diplomacy, talked about no more than "a balance between what is desirable and what is possible" and 
firmly believed that "good results may be given up in the quest for ever elusive ideal solutions" (Vogelgesang, 1980, p. 125-126). Carter was also set apart from the diplomatic approach of his successor Ronald Reagan because he emphasized a diplomacy that would take into account the internal behaviour of foreign countries in deciding about the kind of relations the United States would maintain with their governments (Forsythe, 2000, p. 247).

Rhetorically, the new administration's foreign policy adopted a completely new focus, and significant changes in vocabulary were introduced with the major discourse being used is that of morality and humanitarianism. Carter expressed the belief that United States foreign policy should drastically alter its priorities towards a nobler "fight against poverty, ignorance, and injustice". He also stated that under his administration American diplomacy would offer "a clearcut preference for these societies which share with us an abiding respect for individual human rights" (Vogelgsang, 1980, p. 110). Four months after his inauguration, Carter told a commencement audience at the University of Notre Dame that he had "reaffirmed America's commitment to human rights as a fundamental tenet of our foreign policy" (Forsythe, 2000, p. 140). The Secretary of State Cyrus Vance, also offered a similar perception to that of President Jimmy Carter. He explained that American intervention in world affairs was meant "to demonstrate America's compassion for the poor and dispossessed around the world," and "to contribute to the cause of peace" (Trimiew, 1997, p. 66).

Carter's views about racial equality were expressed as early as 1971 in his inaugural address as the governor of Georgia. In that speech he announced that "at the end of a long campaign, I... say to you quite frankly that the time for racial discrimination is over...no poor, rural, weak, or black person should ever have to bear the additional burden of being deprived of the opportunity of an education, a job or simple justice."1 Upon election as president, his administration also appeared to be profoundly opposed to the racial discrimination that was widespread in the African continent and especially in South Africa.

In a speech made before the annual meeting of the National Association of the Advancement of Colored People, (NAACP), in 1977, his Secretary of State put the South African government in notice that its relations with the US would deteriorate dramatically if no tangible effort was soon made to reverse the discriminatory apartheid system (Massie, 1998, p. 413-414). Andrew Young, American representative to the United Nations voiced the belief that systemized discrimination was simply unacceptable and stated that "at some point we've got to come to the conclusion that we're no longer going to finance apartheid. When we come to that conclusion, it's amazing how quickly the South Africans will come to their senses" (Massie, 1998, p. 410).

What is important about these statements and others by Carter and his foreign policy team is the kind of expectations they created. In fact, after his election, hope grew among human rights activists that a completely new approach to US-African relations was in sight. This hope was reinforced by the fact that, at the time of his campaign, the Democratic candidate expressed regret that he did not effectively help the civil rights movement in the United States, and promised that if elected president he would remedy that (Schraeder, 1994, p. 215). After assuming office, Jimmy Carter travelled to Africa, thus becoming the first American president to visit that continent. Once there he expressed yet again strong rhetorical commitment to democracy and morality. In a speech in Lagos, Nigeria, he exposed the new outlines of American policy in Africa and proudly announced to the African audience that "we share with you a commitment to majority rule and individual human rights...this commitment shapes our attitude toward your continent" (Rosenbaum, 1994, p. 256).

In 1977, a few months after his election as the Democrat President proudly announced:

"Our concern about Southern Africa is quite unlike the basis for our interest in other parts of the world important to the United States, such as Europe, the far East and the Middle East. Our interest is not strategic...our policy toward Southern Africa is guided by our ideals of liberty and equality and by our commitment to oppose racial and social injustice. We believe that the minority governments of Rhodesia, South Africa and Namibia violate fundamental human rights... we have based our policies on the belief that the peaceful transfer of power to the black majority is not only necessary and desirable but also possible" (Lyman, 2002, p. 26).

Carter clearly tried to outline an interest-free policy that has for basic objective to bring about an unconditional end to racial injustices and peaceful solutions to armed conflicts in Africa as a whole. The President also implied that the many restrictions on actions that had hampered an unbiased approach to the apartheid dilemma in previous administrations were no longer an issue under his human rights-oriented approach to foreign policy and insisted that "there are no hidden meanings in our commitment to human rights, only a positive and sincere expression of our deepest belief as a people" (Jackson, 2007, p. 52).

\footnotetext{
${ }^{1}$ Governor Jimmy Carter inaugural address, Atlanta, Georgia. January 12, 1971. Available online at www.carterlibrary.org.
} 
As far as the Cold War factor is concerned, through his rhetoric Carter displayed a clear sensitivity to the excessive role that containment objectives played in American foreign policy calculations and promised a divergent approach. The President for example, stated that he "believed ... that too many of our international concerns were being defined almost exclusively by the chronic United States-Soviet confrontation mentality" (Smith, 1986, p. 85). Carter also confidently announced in his Notre Dame speech that the United States was "now free of that inordinate fear of Communism which once led us to embrace any dictator who joined in that fear" (Thomson, 2008, p. 99). Cyrus Vance expressed a similar commitment when he declared that, contrary to previous administrations, during Carter's term the US would dramatically depart from the "negative, reactive American policy that [sought] only to oppose Soviet or Cuban movements in Africa" (Davis, 2007, p. 7).

The new approach also involved a greater sensitivity to the various issues of the African continent and to the distinctive cultural and political character of the different countries of these regions. In 1977 Cyrus Vance addressed the plenary session of the NAACP convention at Saint Louis and asserted: "Africa matters very much to the United States. This is a fact more and more Americans are coming to understand... we proceed from a basic proposition: that our policies must recognize the unique identity of Africa. We can be neither right nor effective if we treat Africa simply as one part of the third world, or as a testing ground for East-West competition" (Davis, 2007, p. 29).

This kind of rhetoric gave Carter's administration a different appearance from other administrations which made it no secret that national interest would be a major factor driving American foreign relations. It also generated a generally positive academic verdict on his foreign policy. In his bibliographical book the Future almost Arrived, Itai Nartziznfield Sneth explains that the major contemporary perspective from which the Carter presidency is assessed is a revisionist one. Such a perspective is embraced by authors such as Douglas Brinkley, Peter G. Bourne and Robert A. Strong, who believe that "Carter prophetically and genuinely placed the promotion and protection of human rights at the core of American foreign policy" and that his "... deep convictions were expressed through concern for morality, justice and dignity worldwide" (Sneth, 2008, p. 4).

Accounts of 20th century American foreign policy indeed set Carter's diplomacy as distinctive in terms of the role played by human rights in outlining American relations abroad. Author Jerome J. Shestack for example writes that "President Carter made human rights a key focus of US foreign policy" (1989, p. 17) and Robert A. Strong, believes that Carter's commitment to human rights was "strong and enduring". Author Herbert D. Rosenbaum goes as far as contending that "before Carter, the international human rights movement was in its infancy" (1994, p. 15).

Concerning the role he played in the African history, Gaddis Smith, one of the most important biographers of Carter, emphatically states that "the Carter administration devoted more attention to improving the relations of the United States with the black nations of Africa than had any of his predecessor". He also conveys the belief that the president and his advisers "committed the United States wholeheartedly to racial justice and majority rule" (1986, p. 133). Given the prominence of the apartheid issue in African problems, Carter's approach to this dilemma received special attention. Charles Miller contends that "President Carter's administration briefly put America back in support of the anti-apartheid policies of the rest of the world, but when his term was up, so was that support" (2004, p. 321).

As late as 2008, Alex Thomson who studied in depth different US administrations' policies in South Africa, starting with the Truman administration and ending with that of Bill Clinton contended that "of all the administrations studied in this book, it was President Jimmy Carter's executive that confronted Pretoria to the greatest extent" (2008, p. 89). Thomson further stressed this view point with the contention that despite the criticism directed against Carter's administration because of the lack of real impact his policy had on the course of events in that region, it "could not be accused benignly or otherwise of neglecting South Africa" (2008, p. 92).

The academic assessment of the role played by Cold War calculations in the agenda of Carter was also generally in the democratic president's favour. In his book Beyond Constructive Engagement Elliot P. Skinner argues that a major shift in priorities was introduced with Carter's access to power so that "the long established tendency to perceive African issues almost exclusively in terms of the East-West conflict was subject to some reexamination under the prodding of Andrew Young". The same author also believes that it was because of the departure from previous administrations' line of conduct that Carter and his aides were able to deal with African regional problems independently from any hidden antiCommunist agenda (1986, p. 6). Gaddis Smith sees that Carter and his aides attempted to "treat African issues on African terms, not as elements to be manipulated in a global conflict with the Soviet Union (1986, p. 133).

When comparing the place containment occupied in Carter's African policy to that of his successor, Ronald Reagan, authors generally perceive both administrations as distinctive. In a book having for title The Political Economy of US Policy Toward South Africa, Kevin Danaher contends that contrary to his predecessors and successors, the Democratic president attempted to downplay the American- Soviet rivalry as a factor guiding American-South African relations. By so doing, Danaher believes, Carter was able to "de-legitimized [the Communist factor] sufficiently to be 
temporarily dislodged by a regionalist perspective" (1985, p. 140-142). In that same context Zaki Laidi writes about "a regionalist reputation of the Carter administration" and conveys his belief that such a reputation was well deserved (1990, p. 95). In another book by Danaher, the author states that "with the election of Ronald Reagan, the anti-Communist content of US policy reached its most extreme version yet" (1985, p. 81). J. E. Davis also considers that, contrary to the policy of Jimmy Carter, Reagan's approach to Africa as nothing more than "Cold War realpolitik in disguise" (2007, p. 54).

\section{Declassification and the Alternative Assessment of Carter's African Policy}

The process of advancing a new interpretation of some designated historical events is referred to as historical revisionism. The term is defined in the encyclopedia as "the reexamination of accepted history with an eye toward updating it with newly discovered more accurate and/or less biased information" ("Historical"). Revisiting certain historical events to explore them again in depth from a new angle is an integral part of historical practice. This is due to the fact that each new generation has at its disposal new information, new facts and new methods not available to its predecessors. Marilyn Stokstad, for instance, states that since the 1920's so much has been discovered in China, that ancient Chinese history has been rewritten many times (2005, p. 359).

When discussing the importance of historical revisionism in an article titled "Deniers in Revisionist Clothing", Ben S. Austin, contends that contemporary historians, armed with new documentary data, are in a much better position to assess the slavery era in the American South than were historians writing during slavery or in the decades immediately following emancipation. He also asserts that historians are now better equipped to study the Vietnam War than they were in the 60's or the 70's and that the changing perception of the role of women in the United States and world history is largely the product of the work of historical revisionists who have dared to speak up against the historical invisibility of women. It is also important to mention that African-American historians are now doing the same thing with regard to important contributions of African-Americans.

Since Historians interpretation of the past is shaped by the sources available to them and since "history is never constructed from narratives, but always from documents to be interpreted and judged" (Denedotto, 1921, p. 12), the importance of new documentary and archival evidence in instigating historical revisionism is fundamental. What ought to be mentioned in this context is that, because of the system of secrecy that was first devised in the Second World War and that continued to flourish under the guise of national security, most of the Cold War records were not available to historians. It was not until the mid 1990's that these records became open to public scrutiny, under an initiative of the Clinton administration which displayed a new commitment to reducing government secrecy (Lake, 2000). A large number of policy documents and FBI files were declassified and made available for experts and public alike. Some of these related to the foreign policy of Jimmy Carter and contained a number of Presidential Directives and Policy Review Memorandums that gave better insight into the real place that the Cold War and the containment of Soviet influence occupied in his diplomatic agenda for Africa.

Given the strident rhetoric of the Carter administration and the disinterested foreign policy the president himself professed to support, reference to the Communist threat in Africa in presidential directives and other declassified documents is expected to be minimal. Containment objectives and concerns are also expected to be marginal. What was noticed however is that the same priorities and the same fears that were consistently advocated and expressed by preceding and succeeding administrations also colored Carter's policy in Africa, as clearly seen in the declassified documents. The foreign policy making process for this continent appeared to be strongly influenced by Soviet presence and growing influence in the region.

Reference to this strategic consideration was omnipresent in the memorandums and policy analysis relating to almost every single nation of the African continent. For instance, when Carter ordered a study of American polices toward Algeria and Morocco, he issued clear instructions that "the Soviet role in North Africa" should be the major subject of interest in the background study required and that the policy recommendations that would be made had to take this factor into serious consideration ${ }^{2}$. In the Horn of Africa, the major preoccupation was to determine the exact extent of Soviet and Cuban involvement in the Somali-Ethiopian struggle as clearly shown by Presidential Review Memorandum number

\footnotetext{
2 Jimmy Carter's Presidential Review Memorandum 34, North Africa. April 24, 1978. Available online at: http://www.jimmycarterlibrary.gov/documents/prmemorandums/prm34.pdf 
$21^{3}$. Instead of the expected focus on a swift and peaceful resolution of armed conflicts, priority was given to the need to devise the "best strategies for dealing with the Soviets in that region"4.

What became clear trough the declassified documents is that all decisions concerning various African issues were subordinated to the extent of Soviet influence in the region and the potential threat it represented. Carter's Presidential Directive number four for example equated the need for intervention in South African issues with a broader antiCommunism objective when stating that "the problems of Southern Africa should receive urgent action, because the continuation of guerilla war equates with growing Soviet influence" (Danaher, 1985, p. 150). Furthermore, the role that the United States was to play in the Ogaden War appeared largely dependent on decisions taken by the Soviets, as seen in Presidential Directive number 21. Accordingly the US pledged support for the nation that did not receive assistance from the Communist bloc.

Another indication that American-African relations were seen almost exclusively through the lenses of East-West competition is also perceivable through the same Presidential Directive. Carter, who had consistently rejected and criticized illicit arms transfers by third parties to warring countries and groups, directed his foreign policy aides to inform African leaders, during consultations about the Horn of Africa situation, that the United States was willing to authorize "third country arms transfer to Somalia in the event Ethiopia aided by the Soviet Union or Cuba invades Somalia". In North Africa, American future diplomatic course of action was presented in Presidential Review Memorandum 34 as highly dependent on the "Soviet prospects". Accordingly, when evaluating American interests in the region and pondering over short and long term decisions towards Moroccan and Algerian issues, concern with the spread of Communism to these Northern African countries clearly dominated the administration's foreign policy calculations.

The fact that the global competition with the Soviets and the Communists clearly colored American approach to Africa was better seen in a two hundred-page report which gave clear insights into the degree of priority that was given to dealing with Communist influence. The report was prepared in 1978 as an answer to Carter's requirement that the National Security Council conducts a "review of US policy, concerning American objectives and interests in limiting Soviet-Cuban influence in Africa and the steps that the US might take in support of these objectives"5.

In order to further these objectives, Zbigniew Brzezinski, Carter's National Security Advisor, who wrote the directive, made it clear that the government was willing to contradict itself and its professed values and embrace any policy that would limit the Communist presence in Africa no matter how inconsistent with the administration's earlier policy stance this was. He explicitly stated that "no course of action should be automatically excluded from consideration solely because it will present difficult political problems or would conflict with existing policies". By so doing, the Carter administration conveyed a clear sense of urgency and a conviction that no effort would be spared to fight the spread of Communism in Africa.

The report stated that "it is in the interest of the US to have a peaceful and stable Africa of independent nations where Soviet-Cuban influence is not predominant and where the level of Soviet presence and involvement does not alter the overall global balance between the US and the USSR". What this statement revealed is that Africa for the Carter administration was another arena of American-Soviet competition, and that the same foreign policy ingredients that dominated previous and subsequent administrations, namely concern with the "balance of power" and a vision of a Western values-influenced Africa, were still predominant.

Carter's Presidential Review Memorandum 36 revealed that concern with the Soviet and Cuban presence in Africa was far from being minor as it had the United States government consider any means available to counter that threat including "diplomatic action," and "cooperation with European allies and Arab moderate countries". There was also talk about utilizing organizations such as the United Nations and the Organization for Africa Unity. The Carter administration even began to consider "the potential for a significant Chinese role" in American containment objectives. Furthermore, a number of issues were reported to have raised apprehensions and worries very similar to those of previous and succeeding administrations. These included the belief that the Communist presence in Africa led to "the division of position and influence between East and West [which] could be changed to American disadvantage," and that the situation would soon be similar to Eastern Europe where Communism was predominant. What further intensified American fears was the conviction that a growing number of African states view the Soviets as "supportive and reliable".

\footnotetext{
3 Jimmy Carter's Presidential Review Memorandum 21, The Horn of Africa, March 17, 1977. Available online at: http://www.jimmycarterlibrary.gov/documents/prmemorandums/prm21.pdf

4 Jimmy Carter's Presidential Directive 32, Policy Toward the Horn of Africa, February 24, 1978. Available online at: http://www.jimmycarterlibrary.gov/documents/pddirectives/pd32.pdf

5 Jimmy Carter's Presidential Review Memorandum 36, Soviet/Cuban Presence in Africa. May 23, 1978. Available online at http://www.fas.org/irp/offdocs/prm/index.html 
The other important fact that was noticed was that the all-encompassing 1978 report drew an image of the Soviet Union that was clearly reminiscent of that of the Reagan administration. The Soviets were presented as evil actors with evil designs directed against the West and the USA; their objective was said to center on "the advancement of revolution, strengthening their strategic impact on Middle Eastern events and affecting the flow of oil, and displacing the West and specifically the US from a long-held position of influence".

Instruments to tackle the alarming Communist threat in Africa and to remedy the situation were also proposed. Members of the Carter administration put forward various options that were diplomatic, economic, and military in nature to pressurize the Soviets and force their withdrawal from the African continent. These included enlisting as many allies as possible in that effort, and trying to win African support of American objectives. To achieve that, the Democratic administration would use economic help "as a bribe" and various assistance programs that would bring the West and the United States closer to Africa and "give the appearance of concern". Military assistance was also considered and had for objective to help "reduce the incentive of countries to seek Soviet assistance and could contribute to improved US African relations".

The solutions proposed also encompassed the possibility of imposing financial and economic sanctions on the intruders. It is quite interesting to notice that such an option was considered during Carter's term due to the fact that it was proposed by the same officials and the same administration that consistently resisted a similar action against the racist and oppressive white government of South Africa. The use of "films, television, books and documents, exchange of person programs" to foster an international rejection of Soviet and Cuban intervention in Africa was also advocated, and this once again reflected the level of priority given to the objective of effectively facing Communist presence in Africa.

The Carter administration's concern with the Communist threat that transpired through the above discussed declassified documents was translated in numerous containment-influenced foreign policy decisions toward the various African issues. American response to regional conflicts in Africa was clearly the byproduct of a potent anti-Communist feeling. The proximity of the Horn of Africa to the Middle East led US foreign policy makers to view it in a boarder global context, and when the Soviet Union decided to support Ethiopia in the Ogaden war, the United States answered by supplying arms to the Somalis. In Angola, as tension intensified when thousands of Soviet-backed Cuban troops were sent to support the Marxist influenced MPLA, the US started providing financial and military assistance to the other proWestern groups that were involved in the conflict.

As far as racial segregation is concerned, Carter, who promised that the human rights record of African countries would determine their future relations with the United States, instead allied his administration with the worst African violators of racial equality because of their strong anti-Communist credentials. For instance, faced with strong international pressure to relinquish power to the black majority of Rhodesia, lan Smith countered with a proposal of an "internal solution" involving a new government that included the black Bishop Abel Muzorewa. While the international community agreed that such a move was "a cham designed to leave power in white hands", Carter declared himself interested in exploring that possibility because Muzorewa was "untainted by Communist backing unlike the most forceful of the black leaders at war with Smith, Robert Mugabe" (Smith, 1986, p. 141).

The support of white governments perpetrating violent human rights abuses against black citizens was more obvious in American-South African relations. Following the Second World War, the whole African continent started to go through the process of decolonization, and, as Kevin Danaher explains, a great number of the newly formed nations started to display a clear preference for the Communist ideology. South Africa's strategic position in the Southern African region and its staunch anti-Communism convinced many in the Jimmy Carter administration of the need for the Afrikaner government's cooperation against Communism. Most importantly, it hampered an unbiased, human rights-based approach to the apartheid dilemma.

Accordingly, the United States did not allocate the effort or seriousness needed to an effective implementation of the international arms embargo imposed against the republic because of its blatant disregard of the rights of the blacks and the colored. Furthermore, it consistently refrained from imposing strict economic sanctions and other punitive measures so as not to antagonize an important partner in the wide anti-Communist campaign. The human rights dimension inherent in American relations with the white South African government appeared marginal and globalist concerns took precedence over any other humanitarian consideration.

\section{Conclusion}

Thanks to the declassification of Cold War archives, it became clear that, during the 1970's, American policy for Africa was strongly influenced by constraints posed by the international environment and the ongoing Cold War. The various decisions adopted by the Carter administration did not deviate from the usual line of foreign policy conduct. The foreign 
policy reflected through the declassified documents studied in this research centered on containing the Communist growing influence and on devising appropriate strategies to deal with Soviet and Cuban presence in Africa. Faced with an African political scene that was dominated by armed conflicts, civil wars and unrest produced by strict racial segregation, Carter focused primarily on maintaining the global balance of power. While rhetorically deemphasizing East-West confrontation, his administration manipulated internal African conflicts for a larger global purpose, supported and financed pro-Western factions of warring groups and countries, and refrained from imposing pressure on white minority governments because of the role they were expected to play in the American anti-Communist crusade. The opening of Cold War archives therefore allowed an alternative reading of Carter's policy in Africa, a reading that diverged significantly from the one perpetrated by some historians and biographers. It also proved beyond doubt that Carter's African policy did not differ from that of previous and succeeding American administrations.

\section{References}

Austin, Ben S. Deniers in Revisionist Clothing. Retrieved August 30, 2005, from http://www.mtsu.edu/daustin/revision.htm

Miller, Charles. (1987). Sanctions against South Africa. World Politics, 39, 147-73.

Borstelmann, Thomas. (2003). The Cold War and the Cold Line. Harvard: Harvard University Press,

Carpenter, Ted Galen. (1985). The United Sates and Third World Dictatorships: A Case of Benign Detachment. Cato Policy Analysis. Retrieved September 15, 2010, from http://www.cato.org/pubs/pas/pa058.html

Coker, Christopher. (1986). The United States and South Africa, 1968-1985: Constructive Engagement and Its Critics. Texas: Duke University Press.

Danaher, Kevin. (1985). In Whose Interest?: A Guide to U.S.-South Africa Relations. Washington: Institute for Policy Studies.

----. (1985). The Political Economy of U.S. Policy toward South Africa. Colorado: Westview Press

Davies, J. E. (2007). Constructive Engagement?: Chester Crocker \& American Policy in South Africa, Namibia \& Angola. Ohio: Ohio University Press.

Denedetto, Croce. (1921). Theory and History of Historiography. Trans. Douglas Ainslie. London: George G. Harrap.

Dobson, Alan, and Steve Marsh. (2001). US Foreign Policy since 1945. London: Routledge.

Forsythe, David. ( 2000). The United States and Human Rights: Looking Inward and Outward. Nebraska: University of Nebraska Press.

-----. (2000). Human Rights and Comparative Foreign Policy. New York: United Nations University Press.

Jackson, Donna. (2007). Jimmy Carter and the Horn of Africa: Cold War Policy in Ethiopia and Somalia. North Carolina: McFarland \& Company.

Jordanova, Lumilla. (2000). History in Practice. New York: Arnold Publishers.

Kline, Benjamin. (1997). Profit Principle and Apartheid, 1948-1994: the Conflict of Economic and Moral Issues in the United States-South African Relations. New York: Edmin Mellen Press.

Lake, Eli J. (2000). Clinton Declassification Policies Secure; Policies may not be. United Press International. Retrieved September 14, 2005, from http://www.fas.org./sgp/news/2000/11/upi111400.html

Laidi, Zaki. (1990). The Superpowers and Africa: The Constraints of a Rivalry, 1960-1990. rans. Patricia Baudoin. Chicago: University Of Chicago Press, September 1990.

Layman, Princeton. (2002). Partner to History: The U.S. Role in South Africa's Transition to Democracy. Washington: Institute of Peace Press.

Massie, Robert. (1998). Loosing the Bonds. New York: Nan A. Talese.

Rosenbaum, Herbert. (1994). Jimmy Carter: Foreign Policy and Post-Presidential Years. Connecticut: Greenwood Press.

Schraeder, Peter J. (1994). United States Foreign Policy toward Africa: Incrementalism, Crisis and Change. Massachusetts: Cambridge University Press.

Shestack, Jerome. ( 1989). Human Rights, the National Interest, and U.S. Foreign Policy. Annals of the American Academy of Social and Political Science, 506, 17-29.

Skinner, Elliott P., ed. (1986). Beyond Constructive Engagement: United States Foreign Policy Toward Africa. Minnesota: Paragon House.

Smith, Gaddis. (1986). Morality, Reason, and Power: American Diplomacy in the Carter Years. New York: Hill and Wang Publishers.

Sneth, Itai Nartziznfield. (2008). The Future almost Arrived. New York: Peter Lang.

Stokstad, Marilyn. (2005). Art History. New Jersey: Pearson Education.

Strong, Robert. (2000). Working in the World: Jimmy Carter and the Making of American Foreign Policy. Louisiana: Louisiana State University Press.

Thomson, Alex. (2008). U.S. Foreign Policy towards Apartheid South Africa: Conflict of Interests. New York: Palgrave Macmillan.

Trimiew, Darryl. (1997). God Bless the Child that's Got its Own. Atlanta: Scholars Press.

Vogelgsang, Sandy. (1980). American Dream, Global Nightmare: The Dilemma of U.S. Human Rights Policy. New York: W W Norton \& Co Inc. 
